\title{
Menggagas Peradilan Etik Penyelenggara Negara Di Indonesia
}

\section{Harmoko M Said}

Pascasarjana Ilmu Hukum Universitas Indonesia, Jakarta, Indonesia E-mail:harmokomsaid@gmail.com

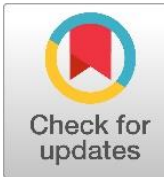

\begin{tabular}{|c|c|}
\hline Dikirim: 17/02/202( & Dipublikasi: 25/3/2021 \\
\hline Info Artikel & Abstract \\
\hline $\begin{array}{l}\text { Keywords: } \\
\text { Initiate; Ethics Court; } \\
\text { State Administrator. }\end{array}$ & $\begin{array}{l}\text { The more complex the problems of state governance are so that corruption, } \\
\text { collusion and nepotism are increasingly becoming serious concerns. As for } \\
\text { the purpose of this writing is to develop the science of constitutional law in } \\
\text { the field of state administration ethics considering the development of an } \\
\text { increasingly democratic Indonesian society, demanding an ethical justice } \\
\text { system that is effective, efficient, professional, transparent, accountable and } \\
\text { reliable for public officials and aims for the rule of law paradigm. law is in } \\
\text { line with the rule of ethics paradigm. The type of research used is juridical } \\
\text { normative, namely explaining various literatures and / or literature. } \\
\text { research results in initiating ethical judiciary for state administrators in } \\
\text { Indonesia, due to the increasing number of ethical code enforcement } \\
\text { agencies in each branch of power. The Rule of Etich is an instrument that } \\
\text { must be implemented for all citizens in the life of the nation and state, in } \\
\text { initiating an ethical court in Indonesia it is very urgent. The urgency of } \\
\text { establishing an ethical judiciary in Indonesia is due to philosophical factors } \\
\text { as reflected in the Pancasila that all five precepts are ethical grounds, } \\
\text { juridical factors as regulated in the 1945 Constitution and MPR Decree } \\
\text { No.V1 / MPR / 2001, with this juridical foundation, it is clear that the } \\
\text { organizers the state is obliged to behave properly. While the sociological } \\
\text { factor is the increasing number of ethicalcode enforcement agencies in each } \\
\text { power clump, therefore the consolidation of ethical code enforcement } \\
\text { agencies and the establishment of ethical courts is urgent due to the weak } \\
\text { adjudication process of the Institute. }\end{array}$ \\
\hline
\end{tabular}

Kata Kunci:

Menggagas; Peradilan Etik; Penyelenggara Negara.

\begin{abstract}
Abstrak
Semakin kompleks persoalan tata kelolah negara sehingga korupsi, kolusi dan nepotisme semakin menjadi perhatian serius hal demikian bukan karena lemahnya peraturan perundang-undangan tetapi krisisnya etika dalam penyelenggaraan negara. adapun tujuan penulisan ini adalah untuk mengembangkan ilmu hukum tata negara dalam bidang etik penyelenggara negara mengingat perkembangan masyarakat indonesia yang semakin demokratis, menuntut adanya sistem peradilan etika yang efektif, efisien, professional, transparan, akuntabel dan terpercaya bagi pejabat publik dan bertujuan agar paradigma rule of law sejalan dengan paradigma rule of ethics. jenis penelitian yang digunakan adalah yuridis normatif yaitu menjelaskan berbagai literatur dan atau kepustakaan. hasil penelitian dalam $\underline{\text { menggagas peradilan etik bagi penyelenggara negara di indonesia, dikarena }}$
\end{abstract}


DOI:

10.47268/sasi.v27i1.266 semakin banyakya lembaga penegak kode etik di masing-masing cabang kekuasaan. Rule Of Etich merupakan satu instrumen yang harus dijalankan bagi seluruh warga negara dalam kehidupan berbangsa dan bernegara, dalam menggagas peradilan etik di indonesia sudah sangat urgen. urgennya pembentukan peradilan etik di Indonesia di karena faktor filosofis sebagaimana tercermin dalam Pancasila bahwa semua sila panca sila merupakan landasan etik, faktor yuridis sebagaimana di atur dalam UUD 1945 dan Tap MPR No.V1/MPR/2001, dengan adanya landasan yuridis ini menjelaskan bahwa penyelenggara negara diwajibkan untuk berperilaku baik. Sementara faktor sosiologi adalah semakin banyaknya Lembaga penegak kode etik disetiap rumpun kekuasaan oleh karenanya konsolidasi Lembaga-lembaga penegak kode etik dan pembentukan peradilan etik menjadi urgen dikarenakan lemahnya proses ajudikasi lembaga tersebut.

\section{A. PENDAHULUAN}

Sistem ketatanegaraan Indonesia pasca amandemen sudah cukup banyak berdiri lembagalembaga penegak kode etik dalam jabatan-jabatan publik. Oleh karena dengan menjamurnya lembaga-Lembaga penegak kode etik di setiap cabang kekuasaan, maka seharusnya pelembagaan peradilan etik dapat dibentuk dan di Lembagakan untuk mendapatkan kepastian hukum.

Munculnya gagasan lembaga court of ethics yang di prakarsai oleh Jimly Asshiddiqie dan kawan-kawan waktu konferensi hukum tata negara yang digelar di Padang bulan September 2015. Gagasan pembentukan pengadilan etik Penyelenggara Negara merupakan gagasan baru seiring dengan terbentuknya berbagai lembaga negara baik yang dibentuk oleh Undang-undang Dasar 1945 hasil amandemen maupun organ negara yang telah terlebih dahulu ada sebelum perubahan Undang-undang dasar. ${ }^{1}$

Beberapa kesempatan juga disaat menyampaikan perkuliahan Jimly kerap menyuarakan tentang pentingnya rule of ethics sebagai salah satu landasan berbangsa dan bernegara. Pemikirin ini Seakan menjadi kulminasi dari beberapa pemikiran-pemikiran sebelumnya, untuk merealisasikan tesis tersebut, perubahan ke lima UUD 1945 patut menjadi momentum melembagakan peradilan etik (court of ethics) dan atau memanfaatkan Lembaga-lembaga negara yang sudah ada seperti komisi yudisial.

Adanya pergeseran orientasi dan cara pandang manusia dalam memecahkan persoalan kehidupan menyebabkan wujud perubahan nilai-nilai serta standar etika yang berlaku. Pada kenyataannya, kita mengetahui bahwa eksistensi individu bukanlah semata-mata produk dirinya, tetapi juga lingkungan sosialnya. Manusia hakikatnya berdimensi monopluralis sekaligus bagian dari lingkungan sosialnya, sehingga memiliki tingkat kesadaran yang berbedabeda tentang nilai hidup. Manusia sebagai pelaku juga sebagai pengkritik moral, baik itu sebagai konsekwensi inteleransi dengan sesama maupun tatanan sistem kehidupan yang hadir. ${ }^{2}$

Berdasarkan uraian diatas bahwa Etika tidak lagi menjadi sumber norma yang abstrak, melainkan tumbuh dan berkembang sebagai norma yang lebih konkret dalam kehidupan berbangsa dan bernegara. Praktik bernegara telah memperlihatkan tidak hanya di dominasi oleh rule of law semata, tetapi juga urgensi penegakan etika dan moralitas (rule of ethics) bagi seluruh warga negara. Etika telah melekat hampir disetiap poros-poros kekuasaan negara, Baik

1 Asshidiqie, Jimly. (2006). Perkembangan dan Konsolidasi Lembaga Negara Pasca Reformasi, Jakarta: Sekjen Dan Kepaniteraan. h. 98.

2 Palese, Emma. (2013). Ethics without Morality, Morality without Ethics-Politics, Identity, Responsibility in Our Contemporary World, Open Journal of Philosophy, 3 (3), 366-371. DOI: 10.4236/ojpp.2013.33055, h. 366

$$
\text { 25|SASI Vo1. } 27 \text { No.1, Januari - Maret } 2021
$$


dalam kekuasaan eksekutif, legislatif dan yudikatif.

Setelah Perubahan UUD 1945 sebanyak empat kali, pengawasan terhadap pejabat negara dan pemerintahan semakin diperkuat dengan dibentuknya banyak lembaga pengawas eksternal yang mengawasi masalah etika dan profesionalitas aparatur lambaga negara. Misalnya saja Komisi Yudisial, Ombudsman, Kompolnas, Komisi Kejaksaan, dan Majelis Kehormatan Dewan. Menjamurnya dewan pengawas etik setelah reformasi politik dan konstitusi, menandai bawha rule of ethic telah merambah disegala sendi-sendi kekuasaan eksekutif, legislatif, maupun yudikatif. Namun harus diakui, diperlukan sebuah konsolidasi kelembagaan dari pengawasan etik yang telah ada dengan menata pelembagaan secara terpadu. Saat ini tumpang tindih kewenangan pengawasan etik belum dirumuskan dengan baik. Hal ini dibuktikan dengan lemahnya proses ajudikasi yang diselesaikan secara internal. Tidak heran jika banyak dugaan pelanggaran etik prosesnya menjadi gamang atau dalam bahasa lain kerap ditemukan hasil temuan pelanggaran etik menjadi "gembos". Oleh karena itu rule of ethic dalam UUD 1945 dituntut untuk mampu mengakomodir pelembagaan peradilan etik bagi pejabat negara maupun pejabat pemerintahan. Terdapat dua alternatif konsolidasi kelembagaan bagi organ-organ pengawas etik yang telah ada.

Ditandai dengan menjamurnya komisi- komisi negara pengawas etika dan perilaku, baik yang bersifat independen ataupun non independen. Seperti misalnya Ombudsman, Komisi Kejaksaan, dan Komisi Kepolisian Nasional (KOMPOLNAS). Organ-organ tersebut hadir sebagai watchdog dalam mengawal proses penyelenggaraan pemerintahan. ${ }^{3}$ Ketua Mahkamah Agung Amerika Serikat Earl Warren pernah mengatakan, "In civilized life, law floats in a sea of ethics" (Dalam kehidupan yang beradab, hukum mengapung di atas samudra etika). ${ }^{4}$ Earl Warren menyebut hukum itu sebagai sesuatu yang hanya dapat tegak, berlayar, bergerak di atas etika. Etika adalah landasan bagi hukum dan mengapung di atas samuderanya. Lebih lanjut beliau menyatakan hukum itu tak mungkin tegak dengan cara yang adil jika air samudera etika tidak mengalir atau tidak berfungsi dengan baik.

Diperlukan penataan untuk mengembangkan infrastruktur etika jabatan-jabatan publik dan etika profesional yang berbasis pada etika sosial yang berfungsi dengan baik dalam mengendalikan perilaku ideal warga masyarakat. Karena itu, untuk tumbuh dan berkembangnya "rule of law" diperlukan basis sosial yang luas berupa bekerjanya sistem etika sosial dalam masyarakat. Jika hukum diumpamakan sebagai kapal sementara etika itulah samuderanya. Maka Kapal hukum tidak mungkin dapat berlayar mencapai pulau keadilan, jikalah air samuderanya kering dan tidak berfungsi.

Sekarang etika sosial dan moralitas berbangsa kita justru sedang mengalami anomi, yaitu suatu keadaan seolah tanpa norma. Akhlak bangsa merosot karena kebebasan yang tidak terkendali. Rumah ibadah semua agama penuh, tetapi perilaku para penganut agama sehari-hari tidak mencerminkan kemuliaan ajaran agama yang diyakini. Bagaimana hendak mengharapkan hukum tegak dengan adil, jika sistem norma sosial dalam kehidupan bermasyarakat tidak berfungsi dengan baik dalam mengendalikan kualitas dan integritas perilaku kita sebagai warga masyarakat.

Oleh sebab itu, agar hukum dapat tegak dan terjaga dengan baik, maka pembangunan kesadaran etika masyarakat sangatlah urgen. Etika pada dasarnya lebih luas dari pada hukum. Setiap pelanggaran terhadap hukum, kebanyakan adalah pelanggaran juga terhadap etika. Akan tetapi sesuatu yang melanggar etika belum tentu melanggar hukum. Etika lebih luas, bahkan dapat dipahami sebagai basis sosial bagi bekerjanya sistem hukum. Jika etika diumpamakan

3 Rishan, Idul. (2017). Justifikasi Pelembagaan Peradilan Etik. Dialogia Iuridica: Jurnal Hukum Bisnis Dan Investasi, 9 (1), 092-111. https://doi.org/10.28932/di.v9i1.733, h. 93.

4 Asshiddiqie, Jimly. (2015). Peradilan Etik Dan Etika Konstitusi, Perspektif Baru Tentang Rule Of Law And Rule Of Ethics \& Constitutional Law And Constitutioal Ethics, Jakarta: Sinar Grafika, h. xiv. 
sebagai samudera, maka hukum merupakan kapalnya.

Lembaga negara yang dibentuk berdasarkan peraturan perundang-undangan bukan UUD 1945 dapat disebut sebagai state auxiliary organ. State auxiliary organ memiliki beberapa variasi diantaranya lembaga negara yang berada dibawah kekuasaan legislative, eksekutif, yudikatif, atau merupakan lembaga negara independen ${ }^{5}$. Di era kepemimpinan Gusdur dibentuk Lembaga Ombudsman, pemebentukan Lembaga ini tidak terlepas dari pengaruh rezim kekuasaan di masa transisi. Pemerintah pada waktu itu nampak sadar akan perlunya lembaga Ombudsman di Indonesia menyusul adanya tuntutan masyarakat yang amat kuat untuk mewujudkan pemerintah yang bersih dan penyelenggaraan negara yang baik atau clean and good governance. Kemudian lembaga ombudsman telah mengalami mistifikasi secara masif ditandai dengan kehadiran Lembaga Ombudsman hampir di setiap daerah. Kehadiran organ ini tidak bisa dipisahkan dari adanya harapan masyarakat akan terwujudnya penyelenggaraan negara dan pemerintahan yang efektif, efisien, jujur, bersih, terbuka, serta bebas dari korupsi, kolusi dan nepotisme.

Pada masa pemerintahan Sosilo Bambang yudoyono lahirlah juga dua komisi pengawas etika, pertama, komisi kejaksaan. Sebagai Lembaga yang mengawasi perilaku kejaksaan Yang memiliki tugas untuk mendorong transparansi dan akuntabilitas para aparatur kejaksaan dalam melaksanakan tugasnya. Oleh sebab itu tidak heran jika komisi ini mempunyai tugas melakukan pengawasan, pemantauan, terhadap kinerja, perilaku jaksa dan, atau pegawai kejaksaan dalam melaksanakan tugas dan wewenangnya yang diatur dalam peraturan perundang-undangan dan kode etik. Kedua, lahir juga suatu Lembaga yang diberi nama Kompolnas hadir di tengahtengah masyarakat untuk menjadi jembatan aspirasi warga sipil terhadap kinerja dan etika perilaku, serta integritas aparat kepolisian.

Sementara dalam tubuh kekuasaan yudikatif, Kita mengenal organ independen yang dinamakan Komisi Yudisial (KY). Sebagai constitutional organ komisi yudisial hadir memberikan harapan bagi para justice seeker untuk menuntut adanya akuntabilitas dalam kekuasaan kehakiman. Sebagai instrumen trust recovery warga negara, kehadiran komisi yudisial adalah bentuk demokratisasi dalam rumpun kekuaasaan yudikatif. Sebab hadirnya komisi yudisial dalam struktur ketatanegaraan RI, memberi porsi bagi masyarakat sipil untuk terlibat secara langsung mulai dari proses pengangkatan sampai dengan kemungkinan proses pemberhentian hakim. Dalam hal ini komisi yudisial diberi tugas untuk mengemban, menjaga serta mengoreksi etika dan perilaku para wakil tuhan di negeri ini.

Masih banyak lagi oraganisasi yang memiliki tugas dan kewenangan untuk menegakan rule of ethics juga terpoliferasi pada organisasi dan profesi di Indonesia. Seperti misalnya dokter, advokat, notaris, guru, pegawai negeri sipil, akuntan, bahkan sampai dengan jurnalis, adalah bentuk organisasi dan profesi yang dibalut beradasarkan prinsip-prinsip etika, perilaku, dan moralitas. Dengan demikian tidaklah berlebihan jika kita mengatakan bahwa bangsa kita sedang "kecanduan" dalam menegakkan rule of ethics dalam setiap sendi-sendi berbangsa dan bernegara. Seakan menghidupkan kembali tesis yang di bangun oleh Franz Magnis Suseno bahwa etika dan moralitas akan menjadi orientasi dalam kehidupan berbangsa dan bernegara. Sebelum Magnis Suseno berpendapat tentang etika dan moral seorang tokoh bernama Rousseau sudah menegaskan tentang keniscayaan negara membuat "right" (kebenaran) mengatasi "might" (kuasa kekuatan), dan "duty" (kewajiban) mengatasi "obedience" (ketundukan).

Kemudian John Rawls menegaskan bahwa bangunan kekuasaan hanya mungkin, jika ia tegak di atas prinsip moral yang menjunjung tinggi kebajikan dan keadilan. Di sini Rousseau dan Rawls sama-sama menggemakan kembali ajaran Aristoteles tentang keniscayaan penegakan kebajikan dan keadilan dalam kolektivitas manusia. Aristoteles juga menegaskan bahwa kekuasaan dan hukum tak terpisahkan semata-mata karena keduaduanya berlandaskan

5 Iswandi, Kelik., Prasetyoningsih, Nanik. (2020). Penyelesaian Sengketa Kewenangan Lembaga Negara Independen di Indonesia. SASI, 26 (4), 434-446. https://doi.org/10.47268/sasi.v26i4.283, h. 436. 
pada etika pada pemuliaan prinsip kebajikan dan keadilan itu.

Perkembangan rule of ethics juga sudah berkembang di 50 negara bagian Amerika Serikat semuanya dan telah membentuk sistem kode etik bagi para pejabat di setiap poros cabang kekuasaan. Dari 50 negara bagian di 42 negara di antaranya telah terbentuk ethics commission yang bekerja secara independen dan efektif dalam mengawal dan menegakkan kode etik bagi para pejabat publik di masing-masing negara. Bahkan fenomena yang sama telah terjadi di negara-negara lain seperti Eropa, Australia, Kanada, dan Amerika Latin. ${ }^{6}$

Sejauh ini paradigma rule of ethics belum diikuti dengan infrastruktur kelembagaan yang menegakkannya. Secara keseluruhan organ-organ yang berfungsi sebagai watchdog masih bekerja secara konvensional. Dan Lembaga-lembaga yang menegakan kode etik masih dilaksanakan secara tertutut sehingga probemnya masih sumir dan enyisahkan persoalan. Sampai saat ini hanya ada satu pelembagaan peradilan etik secara terbuka yaitu hanya Dewan Kehormatan Penyelenggara Pemilihan umum (DKPP). Institusi ini hadir sebagai terobosan peradilan etika secara terbuka.

Pentingnya pelembagaan peradilan etik sebab dalam menyelesaikan problem etik penyelenggara negara tidak cukup hanya diselesaikan oleh majelis atau komisi internal seperti misalnya kompolnas dll, seperti yang disebutkan diatas dan sepanjang etik di diberikan kewenangan pada komisi internal maka tidak heran akan menjadi "macam ompong". Dalam catatan sejarah, jumlah anggota DPR yang diberhentikan karena melanggar kode etik baru 1 orang. Kasus-kasus dugaan pelanggaran kode etik lainnya kandas karena mekanisme di lingkungan internal Badan Kehormatan DPR sendiri. H. Azidin dari Fraksi Partai Demokrat Periode 2004-2009 merupakan anggota DPR pertama dan satu-satunya yang pernah dipecat dalam sejarah keanggotaan DPR. Sesudah itu tidak pernah lagi ada sanksi yang dijatuhkan kepada anggota DPR yang dilaporkan melakukan dugaan pelanggaran kode etik DPR.

Kasus dibentuknya Majelis Kehormatan Hakim (MKH) Mahkamah Konstitusi (MK) atas dugaan pelanggaran kode etik oleh Hakim Arsyad Sanusi dan MKH Mahkamah Agung (MA) atas dugaan pelanggaran kode etik oleh Hakim Agung Ahmad Yamani juga dapat dipakai untuk menjelaskan buruknya sistem tertutup itu. Ketika menyidangkan Hakim Arsyad Sanusi, MKH MK bersidang secara tertutup dan hasilnya Arsyad Sanusi diminta mengundurkan diri untuk pensiun dini. Hal ini persis sama dengan Hakim Agung Ahmad Yamani beberapa bulan kemudian yang juga diberi kesempatan untuk mengajukan permohonan pensiun dini, tanpa kejelasan apakah terbukti melanggar kode etik atau tidak.

Padahal untuk kasus Arsyad Sanusi di MK, Dewan Kehormatan Komisi Pemilihan Umum (DK-KPU) memeriksa salah seorang anggota KPU Andi Nurpati atas pengaduan dugaan pelanggaran kode etik yang melibatkan peran Hakim Konstitusi Arsyad Sanusi dan Calon Anggota Legislatif 2009 Dewi Yasin Limpo. Hasil pemeriksaan DK-KPU dalam persidangan terbuka membuktikan, Andi Nurpati terlibat pelanggaran di beberapa tempat, termasuk dalam kaitan dengan kasus Arsyad Sanusi dan Dewi Yasin Limpo. Andi Nurpati diberhentikan dari keanggotaan Komisi Pemilihan Umum, sedangkan MKH MK tidak menyatakan bahwa Hakim Arsyad Sanusi melanggar kode etik, melainkan hanya menerima niat baik Hakim Arsyad Sanusi untuk mengajukan permohonan pensiun dini dari jabatan hakim konstitusi.

Putusan MKH MA atas dugaan pelanggaran kode etik Hakim Agung Ahmad Yamani juga demikian. Putusan melalui persidangan tertutup memberi kesempatan kepadanya untuk mengajukan permohonan pensiun dini. Putusan demikian dinilai bukan sebagai sanksi atau hukuman bagi Ahmad Yamani, melainkan kemudahan untuk melepaskan diri dari sorotan masyarakat.

Agar paradigma rule of law sejalan dengan paradigma rule of ethics. Maka dibutuhkan satu model pelembagaan peradilan etik di Indonesia. Agenda penting ini menjadi patut dan

${ }^{6}$ Asshiddiqie, Jimly. Op.Cit.

28|S A S I Vol. 27 No.1, Januari-Maret 2021 
layak dikembangkan serta mendapat perhatian serius untuk mewujudkan era baru rule of ethic. Pembaharuan dibutuhkan mengingat perkembangan masyarakat Indonesia yang semakin demokratis, menuntut adanya sistem peradilan etika yang efektif, efisien, professional, transparan, akuntabel dan terpercaya bagi pejabat publik. Oleh karena itulah "Menggagas Peradilan Etik Penyelenggara Negara Di Indonesia" merupakan kajian yang perlu direspon dan dikaji dalam ruang lingkup akademik.

\section{B. METODE PENELITIAN}

Penulisan ini menggunakan metode penelitian hukum yuridis normatif (normatif research). Sesuai jenis dan sifat penelitiannya, maka sumber data yang digunakan dalam penulisan ini adalah data sekunder yang terdiri dari bahan hukum primer berupa: peraturan perundang-undangan yang berkaitan dengan tema pembahasan. Bahan hukum sekunder dalam penelitian ini terdiri dari buku-buku, jurnal ilmiah dan artikel ilmiah yang dapat memberi penjelasan tentang bahan hukum primer. Sedangkan bahan hukum tersier berupa Kamus Besar Bahasa Indonesia (KBBI) dan lain sebagainya dalam menemukan defenisi dari istilah-istilah dalam membahas pelembagaan peradilan etik penyelenggara negara di Indonesia.

\section{PEMBAHASAN}

Secara etimologi istilah etika berasal dari bahasa Yunani "ethos". Kata Yunani "ethos" dalam bentuk tunggal mempunyai banyak arti yaitu tempat tinggal yang biasa, padang rumput, kandang, kebiasaan, adat, akhlak, watak, perasaan, sikap dan cara berfikir. Dalam bentuk jamak "ta etha" artinya adalah adat kebiasaan. Istilah lain yang identik dengan etika, yaitu usila (Sanskerta), lebih menunjukkan kepada dasar-dasar, prinsip, aturan hidup (sila) yang lebih baik $(s u)$. Istilah selanjutnya adalah Akhlak (Arab), berarti moral, dan etika berarti ilmu akhlak. ${ }^{7}$

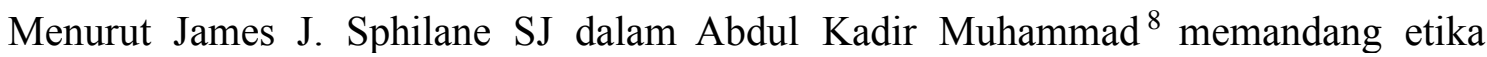
atau ethics senantiasa memperhatikan atau mempertimbangkan tingkah laku manusia dalam pengambilan keputusan moral. Etika mengarahkan atau menghubungkan penggunaan akal budi individual dengan objektivitas untuk menentukan "kebenaran" atau "kesalahan" dan perilaku seseorang terhadap orang lain. Etika lahir sebagai perwujudan suatu bentuk aturan yang tertulis. Dibuat secara sistematik secara terencana. Etika didasarkan pada prinsip moral yang ada. Ketika dibutuhkan etika dapat difungsikan sebagai alat untuk menghakimi berbagai macam tindakan yang dinilai menyimpang dari etika.

Secara filosofis sikap patuh profesional hukum terhadap kode etik merupakan ketaatan naluriah, bersatu dengan pikiran, jiwa serta langkah perilaku para profesional. Kepatuhan terbentuk dari masing-masing orang, bukan karena suatu paksaan. sikap etis profesional muncul, yakni ketika para profesional merasa jika dia melanggar kode etiknya. Dia merasa profesinya akan rusak dan yang rugi adalah diri sendiri.

Etika pemerintahan merupakan dua hal yang berbeda tetapi karena pada bagian ini akan digabungkan antara etika dan pemerintahan, jadi etika akan diterapan aturan etika dalam pemerintahan. Etika pemerintahan adalah Bagian dari yurisprudensi praktis, atau filosofi hukum, yang mengatur jalannya pemerintahan dan hubungannya dengan orang-orang yang diaturnya. Ini mencakup masalah kejujuran dan transparansi dalam pemerintahan, menangani hal-hal seperti suap, korupsi politik, korupsi polisi, etika legislatif, etika peraturan, konflik kepentingan, menghindari munculnya ketidakwajaran, pemerintahan terbuka, dan etika hukum.

Kantor etika pemerintah AS diprakarsai oleh Undang-Undang Etika dalam Pemerintahan tahun 1978 untuk memberikan arahan kepemimpinan dan kebijakan secara keseluruhan untuk

7 Ismail, (2017). Etika Pemrintahan Norma, Konsep Dan Praktek Pemerintahan, Yogyakarta: Lintang Rasi Aksara Books, h. 1.

8 Muhammad, Abdul Kadir. (2006). Etika Profesi Hukum, Bandung: Citra Aditya Bakti, h. 13 
program etika di cabang Eksekutif pemerintah. Gambaran yang sama ini tercermin, meskipun secara tidak merata, di seluruh administrasi negara bagian AS. Secara keseluruhan, model etika sektor publik AS telah menjadi sangat diatur dan, beberapa orang akan mengatakan, rumit. ${ }^{9}$

Maka berdasarkan hal diatas bahwa eksistensi kode etik profesi sangatlah penting. Kode etik memiliki tiga fungsi, yaitu sebagai sarana kontrol sosial, sebagai pencegah campur tangan pihak lain, dan sebagai pencegah kesalahpahaman dan konflik. Etika menurut Magnis Suseno berguna untuk membantu manusia mencari orientasi secara kritis dalam berhadapan dengan moralitas yang membingungka. ${ }^{10}$ Menurut Agus Santoso, ${ }^{11}$ ajaran etika atau moral merupakan sikap etis yang harus dilakukan dalam menjalankan aktivitas manusia sebagai makhluk sosial, karena perilaku etis itu sebagai bagian integral dari sikap hidup dan perikehidupan manusia sebagai pengemban profesi. Keputusan pada etika atau moral tergantung kepada akhlak yang bersangkutan. Prinsipnya etika atau moral bersifat individu atau subjektif.

Tetapi dalam tata pergaulan sosial diperlukan adanya standar yang ditetapkan dalam pedoman atau panduan perilaku. Apalagi jika dikaitkan dengan penyelenggara negara, maka diperlukan pedoman yang disebut kode etik tertulis. Penting untuk dipahami bahwa tujuan utama kaidah moral atau etika adalah untuk melindungi dan menjaga martabat moral penyelenggara negara maupun melindungi perbuatan menyimpang dari perlakuan penyandang profesi dimaksud, sehiangga menurut Jimly Assidiqie bahwa untuk mengembangkan pengertian baru tentang the rule of law and the rule of ethics ini dalam teori dan praktik. Menurutnya Indonesia memiliki pancasila sebagai sumber hukum dan sumber etika,UUD Negara republik Indonesia tahun 1945 sebagai dokumen bernegara yang berisi kandungan norma hukum konstitusi dan etika konstitusi. Ketetapan MPR No.V1/MPR/2001 tentang etika kehidupan berbangsa yang sampai sekarang masih berlaku resmi sebagai hukum dan etik. Karena itu, Pancasila harus dipahami bukan saja sebagai sumber hukum, tetapi juga sumbur etika. Demikian pula UUD 1945, bukan hanya berisi hukum konstitusi constitutional ethics yang juga tercermin dalam TAP MPR No.V1/MPR/2001 sebagai haluan politik Negara dalam bidang etika berbangsa dan bernegara.

\section{Perkembangan Etik}

Pada awal mulanya etika hanya di pandang sebagai sesuatu yang bersifat privat dan selalu dikaitkan dengan agama, namun dalam perjalan sejarah etika mengalami perkembangan yang cukup signifikan seorang filusuf Auguste Comte dalam Teori evolusioner lebih cenderung melihat bahwa perubahan sosial yang terjadi merupakan proses yang linear, artinya semua masyarakat berkembang melalui urutan perkembangan yang sama dan bermula dari tahap perkembangan awal dan akhir. Perkembangan masyarakat melewati tiga tahap sebagai berikut: ${ }^{12}$

1) Tahap Teologis (theological stage)

Masyarakat di arahkan oleh nilai-nilai supernatural. Dimana akal budi manusia dengan mencari kodrat manusia yakni sebab pertama dan sebeb terakhir dari segala akibat.

2) Tahap Metafisik (methaphysical stage)

yaitu tahapan peralihan dari keprcayaan terhadap unsur supernatural menuju prinsipprinsip abstrak yang berperan sebagai dasar perkembangan budaya. Hapan metafisik

9 Preston, N. (2000). Local Government, Public Enterprise and Ethics. The Federation Press, 2000, h. 22.

10 Suseno, Franz Magnis. (1991). Etika Dasar: Masalah-Masalah Pokok Filsafat Moral, Yogyakarta: Kanisius, h. 15

11 Santoso, Agus. (2012). Hukum, Moral \& Keadilan Sebuah Kajian Filsafat Hukum, Jakarta: Kencana, h. 83-84.

12 Nugroho, Irham. (2016). Positivisme Auguste Comte: Analisa Epistemologis Dan Nilai Etisnya Terhadap Sains, Cakrawala Jurnal Studi Islam, 11 (2), 167-177. https://doi.org/10.31603/cakrawala.v11i2.192 h. 169 .

$$
\text { 30|SASI Vo1.27 No.1, Januari-Maret } 2021
$$


sebagai transisi dari teologis. Tahap ini sebagai suatu kepercayan akan hukumhukum alam yang asasi yang dapat ditemukan dengan akal budi.

Menggambarkan perkembangan etika dari tahap ketahap, Prof. Jimly meminjam istilahistilah yang dipakai oleh Auguste Comte dipakai juga oleh prof jimly untuk pengertian yang sama sekali berbeda untuk menggambarkan tahap-tahap perkembangan sistem etika. Menurut prof jimly ashidiqee perkembangan etik sudah melewati beberapa fase perkembangan sebagai berikut : ${ }^{13}$
a) Etika teologis
b) Etika ontologis
c) Etika Positivis
d) Etika Fungsional Tertutup
e) Etika Fungsional Terbuka

Bahkan, dari pengertian tersebut, kita dapat pula memperkenalkan pemahaman baru tentang the rule of ethics di samping pengertian tentang the rule of law. Dalam konsepsi Rule of Law tercakup pengertian tentang kitab-kitab hukum atau kode-kode hukum (codes of law) atau kitab undang-undang (books of law) dan pengadilan hukum (court of law). Sedangkan dalam konsepsi "Rule of Ethics" tercakup pengertian kode-kode etik (codes of ethics) atau kode perilaku (codes of conduct) dan sekaligus juga pengertian tentang pengadilan etika (court of ethics). Konsepsi demikian ini tentu belum populer, apalagi mengenai pengertian peradilan dan pengadilan etika, sama sekali belum dikenal di dunia. Artinya, perkembangan sistem etika pada tahap kelima ini dapat dikatakan masih harus dirintis dengan sebaik-baiknya, sebagai inovasi yang diprakarsai oleh bangsa kita untuk kepentingan integritas kemanusiaan di seluruh dunia di masa mendatang. Namun, pengertian tentang peradilan dan pengadilan etika ini perlu terus dipromosikan agar semakin banyak orang yang menyadari pentingnya membangun pengertian baru tentang "rule of ethics", di samping "rule of law".

\section{Pancasila Sebagai Grundnorm Ethic}

Dalam konteks negara, peran etika dan moralitas tidak dapat dipisahkan dari nilai dasar yang menjadi ruh dalam berperilaku berbangsa dan bernegara. Nilai dasar tersebut menjadi pondasi dan guidline dalam menjalankan kehidupan berbangsa dan bernegara. Dalam hukum sendiri, nilai yang dimaksud terkandung dalam grundnorm dalam stupen theory menempati posisi paling dasar sebagai pokok dari staat fundamental norm. ${ }^{14}$

Sebelum dibahasa tentang Pancasila sebagai peletak dasar atau sumber norma etik, maka terlebih dahulu akan dibahas tentang grundnorm, untuk mengetahui grundnorm paling tidak ada dua sudut pandang adalah sebagai berikut : Pertama, Grundnorm dalam Hans Kelsen stufenbeau theory, ${ }^{15}$ dikualifikasikan dalam empat indikator atau karakteristik utama, yaitu: (a) abstrak dan memiliki daya berlaku universal; (b) bukan gesetzt (ditetapkan), namun vorausgesetzt (diasumsikan) oleh akal budi manusia; (c) bukan merupakan bagian dari hukum positif melainkan meta juristic. Kedua, Grundnorm sebagai source of law, dimana grundnorm menjadi sumber berlakunya hukum yang tertinggi dan terakhir (source of the source). Grundnorm menjadi dasar mengapa hukum harus dipatuhi dan sekaligus memberikan pertanggungjawaban mengapa hukum harus dilaksanakan, meskipun tidak ada sanksi. Grundnorm diterima masyarakat secara aksiomatis. ${ }^{16}$

Nilai-nilai Pancasila dijabarkan dalam berbagai peraturan perundangam yang ada. Perundang-undangan, ketetapan, keputusan, kebijaksanaan pemerintah, program-program

13 Asshiddiqie, Jimly. (2014). Peradilan Etika Dan Etika Konstitusi, Jakarta: Sinar Grafika, h. 25.

14 Indrati, Maria Farida. (2007). Ilmu Perundang-Undangan 1, Jenis, Fungsi, Dan Materi Muatan, Yogyakarta: Kanisius, h. 236.

15 Ibid.

16 Ibid. 
pembangunan, dan peraturanperaturan lain pada hakikatnya merupakan nilai instrumental sebagai penjabaran dari nilai-nilai dasar pancasila. ${ }^{17}$ Kedudukan pancasila sebagai dasar negara dalam pembukaan UUD 1945 ini bersifat yuridis - konstitusional. Artinya nilai pancasila sebagai norma dasar negara (Grundnorm, kaidah negara yang fundamental) bersifat imperatif; artinya mengikat dan memaksa semua yang ada didalam wilayah kekuasaan hokum negara RI untuk setia melaksanakan, mewariskan, mengmbangkan dan melestarikannya. Pancasila sebagai dasar - dasar filosofis terdapat dalam Pembukaan UUD 1945 yang merupakan kesepakatan pertama penyangga konstitusionalisme. Dengan tidak diubahnya Pembukaan UUD 1945, maka tidak berubah pula kedudukan pancasila sebagai dasar - dasar filosofis bangunan negara republik Indonesia, yang berubah adalah sistem dan institusi untuk mewujudkan citacita berdasarkan nilai-nilai pancasila dan perkembangan masyarakat. ${ }^{18}$

Hakikat dan esensi atau substansi dari Pancasila merupakan prinsip-prinsip yang sangat mendasar, yang mengatur kehidupan bermasyarakat, berbangsa dan bernegara. Prinsip-prinsip tersebut mencakup nilai-nilai tentang ketuhanan, kemanusiaan, persatuan, kerakyatan dan keadilan. Prinsip-prinsip sebagai nilai-nilai dasar Pancasila tersebut mengatur tata hubungan manusia Indonesia dalam berhubungan dengan Tuhan, dirinya pribadi, dan lingkungannya.

Pancasila didalamnya terdiri dari lima nilai internal yang fundamental dan merupakan memanifestasi dari harkat dan martabat kemanusiaan, sebab peradaban dan asas-asas keadaban merupakan rumusan dan intisari nilai-nilai kemanusiaan yang tertuang di dalam kehidupan dan kebudayaan banga Indonesia dalam arti luas, serta di dalam agama-agama. Menurut Notonegoro didalam idjuga menyatakan bahwa adanya kesamaan kedudukan yang kodrati dengan kesamaan sifat yang kodrati. Pernyataan ini oleh Notonegoro dikemukakan dengan maksud untuk dijadikan pedoman bagi bangsa Indonesia di dalam kehidupan bernegara. ${ }^{19}$

Rule of ethic dalam Pancasila dideskripsikan dengan menunjuk terhadap nilai yang menjadi dasar moral berperilaku. Kelima sila dirumuskan terdiri dari sila-sila yang terpisah secara makna namun menjadi kesatuan dalam nilai dan moral. Sila pertama menunjukkan kedudukan agama sebagai nilai moral ketuhanan dimana masyarakat dalam praktik bernegara tidak menafsirkan antara kedudukan agama dan negara sebagai suatu unsur yang terpisah, melainkan suatu kesatuan yang berkaitan. Ajaran agama sebagai etika berperilaku memiliki kedudukan yang tinggi dan pertama dalam Pancasila.

\section{UUD 1945 sebagai Sumber Etika}

Norma hukum yang tertinggi dan merupakan kelompok pertama dalam hirarki norma hukum negara adalah "staats fundamental norm". Istilah "staat sfundamental norm” ini diterjemahkan oleh Notonagroho dalam pidataonya pada acara dies Natalis Universitas Airlangga yang pertama (10 November 1955) dengan pokok kaidah fundamental negara, ${ }^{20}$ kemudian juniarto ${ }^{21}$ menyebutnya dengan istilah norma pertama, sedangkan A. Hamid S. Attamimi menyebutkan istilah "staat sfundamental norm" ini dengan "norma fundamental negara". ${ }^{22}$

Aturan pokok negara (staatsgrundgesetz) yang merupakan kelompok norma hukum dibawah norma fundamental negara, norma-norma dari aturan dasar negara merupakan aturan yang bersifat pokok dan merupakan aturan umum yang masih bersifat garis besar sehingga masih merupakan norma hukum tunggal. Menurut Hans Nawiasky suatu aturan dasar negara dapat dituangkan dalam suatu dokumen negara yang disebut staatsverssung, atau dapat juga

17 Ihsan, Fahrul. Ekonomi Pancasila: Gagasan Dan Kemungkinan, Jakarta: Pusataka LP3ES, h. 51.

18 Eleanora, Fransiska Novita. (2012). Pancasila Sebagai Norma Dasar Dalam Sistem Hukum Indonesia, ADIL Jurnal Hukum. 3 (1), 141-165. https://doi.org/10.33476/ajl.v3i1.838, h. 142

19 Rishan, Justifikasi Pelembagaan Peradilan Etik, Op.Cit. h. 97.

20 Farida, Maria. Op.Cit. h. 46.

21 Ibid.

${ }^{22}$ Ibid. 
tertuang dalam dokumen negara yang tersebar-sebar yang disebut dengan istilah staatgrundgesetz. ${ }^{23}$

Maka didalam negara republik Indonesia aturan dasar /atau aturan pokok negara tertuang dalam batang tubuh UUD 1945 dan ketetpan MPR serta dalam hukum dasar tertulis yang disebut dengan fungsi ketatanegaraan. Rumusan dalam UUD 1945, sebagai rumusan norma etika setidaknya dapat ditemukan melalui larangan bagi penyelenggaran negara untuk melakukan perbuatan tercela. Rumusan itu akan di jumpai dalam pasal 7A UUD 1945:

"Presiden dan/atau Wakil Presiden dapat diberhentikan dalam masa jabatannya oleh Majelis Permusyawaratan Rakyat atas usul Dewan Perwakilan Rakyat, baik apabila terbukti telah melakukan pelanggaran hukum berupa pengkhianatan terhadap negara, korupsi, penyuapan, tindak pidana berat lainnya, atau perbuatan tercela maupun apabila terbukti tidak lagi memenuhi syarat sebagai Presiden dan/atau Wakil Presiden”.

Konstruksi Pasal 7A yang dijelaskan diatas yaitu menggabungkan antara perbuatan tercela sebagai bagian dari pelanggaran hukum, dalam hal ini perbuatan tercela dimaknai sebagai moral yang berkaitan dengan etika. Dalam hal ini pelanggaran etika (perbuatan tercela) dalam proses hukumnya ditangani oleh Mahkamah Konstitusi yang secara tidak langsung bertindak sebagai court of ethic jika pelanggaran hukum (perbuatan tercela) yang menjadi dasar impeachment presiden. Berdasarkan penjelasan yang dimaksud atas bahwa undang-undang dasar 1945 tidak berlebihan sekirang penulis mengatakan bahwa UUD 1945 sebagai sumber Rule of ethic bagi penyelenggara negara.

Etika merupakan dasar kehidupan berbangsa dan bernegara. Bahwakan etika adalah barometer peradaban bangsa, suatu peradaban bangsa berperdaban tinggi ditentukan oleh bagaimana warga negara bangsa bertindak sesuai dengan aturan main yang disepakati Bersama. Perilaku dan sikap taat pada aturan main yang disepakati Bersama, perilaku dan sikap taat pada aturan wajar, efisien, dan tanpa hambatan berarti.

Didalam ketetapan MPR Nomor VI/MPR/2001 di tentukan pula arah kebijakan etik penyelenggara negara sebagai berikut:

a) Mengaktualisasikan nilai-nilai agama dan budaya luhur bangsa dalam kehidupan pribadi,keluarga, masyarakat, bangsa, dan negara melalui Pendidikan formal, informal dan nonformal.

b) Mengarahkan oreantasi Pendidikan yang mengutamakan aspek Pendidikan yang bersifat terpadu dengan menekan ajaran etik yang bersumber dari ajaran agama dan budaya luhur bangsa serta Pendidikan watak dan budi pekerti yang lebih menekankan pada kecerdasan intelektual.

c) Mengupayakan supaya program pembangunan dan seluruh aktifitas keidupan berbangsa dan bernegara harus dijiwai berdasarkan nilai etika dan ahlak baik tahap perencanaan, pelaksanaan, maupun evaluasi.

Berdasarkan uraian diatas, harus ada upaya untuk membebaskan bangsa dari bahaya krisisnya etika dan mengembalikan etika dan moral bangsa kedalam aktivitas sehari-hari.

\section{Konstruksi Peradilan Etik di Indonesia}

Proses pelembagaan peradilan etik di Indonesia tentu bukanlah hal yang mudah namun perlu melihat bagaimana cara dan motode untuk membangun peradilan etik itu sendiri. Kekuasaan Kehakiman dalam konteks negara Indonesia adalah kekuasaan negara yang merdeka untuk menyelenggarakan peradilan guna menekkan hukum dan keadilan berdasarkan pancasila demi terselenggarannya negara repubik Indonesia. Salah satu agenda penting yang perlu di hadapi di masa depan penegakan hukum di Indonesia, dan hal utama dalam penegakan hukum adalah masalah kekuasaan kehakiman yang merdeka. Berdasarkan Pasal 24 Ayat (2)

${ }^{23}$ Ibid. h. 48.

33 |S A S I Vo1.27 No.1, Januari - Maret 2021 
Perubahan Ketiga UUD 1945, maka yang diberi wewenang oleh UUD 1945 untuk melakukan kekuasaan kehakiman adalah Mahkamah Agung beserta badan-badan peradilan di bawahnya, dan oleh Mahkamah Konstitusi. Badan-badan peradilan sebagai pelaku kekuasaan kehakiman mengemban tugas pokok, yakni melaksanakan public service di bidang pemberian keadilan. ${ }^{24}$

Dewasa ini disetiap sendi-sendi kekuasaan baik itu eksekutif, legislatif maupun yudikatif sudah menjamur Lembaga penegak kode etik sebagaimana disebutkan dimuka. Menjamurnya dewan pengawas etik setelah reformasi politik dan konstitusi, menandai bahwa rule of ethic telah merambah disegala sendi-sendi kekuasaan eksekutif, legislatif, maupun yudikatif. Namun harus diakui, diperlukan sebuah konsolidasi kelembagaan dari pengawas- pengawas etik yang telah ada dengan menata pelembagaan secara terpadu.

Oleh karena menjamurnya Lembaga penegak kode etik maka perlu di lakukan konsolidasi secara kelembagaan untuk menyelaraskan agar tidak terjadi tumpah tindih, dengan banyaknya aturan yang tumpah tindih sehingga mengakibatkan lemahnya proses ajudikasi dan banyak kasus yang tidak terselesaikan. Tidak heran jika banyak dugaan pelanggaran etik prosesnya menjadi gamang atau dalam bahasa lain kerap ditemukan hasil temuan pelanggaran etik menjadi "gembos". Oleh karena itu UUD 1945 sebagai peletak dasar rule of ethic dituntut untuk mampu mengakomodir pelembagaan peradilan etik bagi pejabat negara maupun pejabat pemerintahan. Untuk melakukan konsolidsi terhadap Lembaga etik yang sudah ada, maka untuk itu pembentkan Lembaga peradilan etik hanya bisa dilakukan dengan dua acara sebagai berikut :

Pertama, proses pembentukan suatu Lembaga negara atau peradilan etik bisa dibentuk melalui undang-undang. Dalam hal ini kontruksinya peradilan etik dibentuk sebagai lembaga negara yang mempunyai fungsi mengadili terhadap pelanggaran etik penyelenggara negara. Peradilan etik yang dibentuk dalam Undang-Undang harus dilengkapi dengan kewenangan memutuskan yang bersifat final dan mengikat. Adapun bentuk sanksi yang dikeluarkan oleh peradilan etik dapat berbentuk a) teguran tertulis, b) pemberhentian sementara dari tugas (skors), dan c) perintah untuk melakukan pemecatan, perintah ini disampaikan pada pihak yang berwenang dalam melakukan pemecatan. ${ }^{25}$

Kedua, pemebntukan peradilan etik dapat dilakukan melalui jalur perubahan kelima UUD 1945, dimana pengaturan terkait pelembagaan peradilan etik diatur dalam konstitusi (constitutionally based power) sehingga menjadi organ penting (constitutional importance) konstitusi dalam mengawal etik dan perilaku pejabat negara. Pelembagaan peradilan etik dalam rumpun Kekuasaan Kehakiman bukanlah sebuah hal yang mustahil melainkan sebuah keniscayaan dengan melihat perkembangan rule of ethics.

Konsolidasi kelembagaan dilakukan dengan metode reposition, reshaping, dan redundancy terhadap organ-organ negara yang telah ada sebelumnya. Misalnya perihal reposition. Mereposisi kedudukan Komisi Yudisial dalam kekuasaan kehakiman sehingga KY tidak hanya menjadi Lembaga penegak kode etik hakim saja tapi menjadikan KY sebagai peradilan etik penyelenggara negara untuk mengadili pelanggaran etik bagi penyelenggara negara di indonesia sehingga berfungsi sebagai watchdog terhadap penegakan etika dalam tubuh kekuasaan kehakiman.

Melakukan reshaping atau merampingkan organ-organ yang telah ada. Misalnya dalam kekuasaan eksekutif Ombudsaman, Komisi Kejaksaan, Komisi Kepolisian dll, yang juga berfungsi sebagai pengawas etika pejabat publik dikekuasaan eksekutif, dan nantinya dilembagakan secara integratif (terpadu menjadi satu kesatuan). Begitu juga dalam kekuasaan legislatif terdapat satu organ negara yang secara eksternal terpisah dengan alat kelengkapan

24 Angkasa, Nawa. (2013). Analisis Kedudukan Dan Fungsi Yudikatif Sebagai Pemegang Kekuasaan Kehakiman Dalam Sistem Negara Hukum Di Indonesia. Nizham Journal of Islamic Studies. 02 (1), 84-109. https://e-journal.metrouniv.ac.id/index.php/nizham/article/view/848, h. 109.

${ }_{25}$ Suparman, Eman. (2013). Risalah Komisi Yudisial (Cikal Bakal Dan Wewenang), Jakarta : Secretariat Jendral Komisi Yudisial Republic Indonesia, h. XXVI.

$$
\text { 34|SASI Vol. } 27 \text { No.1, Januari-Maret } 2021
$$


DPR dan DPD. Organ ini menjadi wadah aspirasi untuk menampung dugaan pelanggaran etik para wakil rakyat. Melakukan redundancy atau menghapus beberapa alat kelengkapan organ atau lembaga yang dulunya mempunyai fungsi mengadili pelanggaran etik. Misalnya DKPP, MKD, MKH, dan MKHK. Sebab ke depan semua tahap ajudikasi pelanggaran etik akan diserahkan melalui peradilan etik. Dengan model desainya seperti itu akan berimplikasi bahwa kekuasaan kehakiman bisa dilembagakan dengan adanya Mahakamah Agung (MA), Mahkamah Konstitusi (MK) dan Mahkamah Etik (ME). Melalui sistem yang trikameral, kekuasaan kehakiman akan menjadi tonggak sejarah baru. Tidak hanya menegakkan hukum (rule of law) melainkan juga penegakkan etika (rule of ethics) berbangsa dan bernegara bagi pejabat negara maupun pejabat pemerintahan.

Keberadaan Mahkamah Etik (ME) dalam kekuasaan kehakiman dapat menjadi penguatan bagi sistem ketatanegaraan RI. Sebab dengan adanya Mahkamah Etik, sistem ketatanegaraan kita didukung oleh penegakan hukum dan dikuatkan dengan penegakan etika yang bersifat fungsional terbuka. Dengan demikian rule of law dapat berjalan saling interdeterminan dengan rule of ethics. Sehingga rule of law dapat bekerja berdasarkan code of law yang penegakannya dilakukan oleh MA dan MK. Sedangkan rule of ethics bekerja berdasarkan code of ethics yang penegakanya dilakukan melalui Mahkamah Etik (ME), yang masing-masing dilakukan berdasarkan prinsip independen, akuntabel dan imparsial.

Lembaga peradilan etik yang nantinya tidak hanya terbatas untuk mengadili pelanggaran etika dan moral pejabat negara baik pada lingkup ekskutif, legislatif maupun yudikatif, namun outputnya adalah bagaimana pejabat negara tersebut mampu untuk mempertanggungjawabkan perbuatannya pada masyarakat.

Adapun desain kewenangan yang di harapkan bagi peradilan etik tersebut adalah mampu untuk memberikan sanksi yang tegas bahkan sampai pada tingkat pemberhentian kepada pejabat negara yang melakukan perbuatan melanggar nilai-nilai moral yang berimplikasi pada runtuhnya kedaulatan rakyat itu sendiri sebagai suatu amanah yang diemban saat ia memangku suatu jabatan.

Adapun untuk memastikan tidak terjadinya over laping antara kewenangan lembaga peradilan yang satu dengan lembaga peradilan yang lain, maka perlu adanya harmonisasi mulai dari tataran regulasi yakni peraturan perundang-undangan sampai pada koordinasi dan kerja sama antar internal lembaga peradilan untuk mewujudkan pejabat negara yang beretika dan bermoral dalam upaya untuk mencapai pemerintahan yang lebih baik.

Negara sebagai suatu organisasi kekuasaan memiliki alat perlengkapan untuk merealisasikan tujuan dan keinginan-keinginan negara (staatswill). ${ }^{26}$ Konsep lembaga negara secara terminologis memiliki keberagaman istilah. Di kepustakaan Inggris, sebutan lembaga negara menggunakan istilah "political institution", sedangkan dalam kepustakaan Belanda dikenal dengan istilah "staat organen", sementara itu, bahasa Indonesia menggunakan istilah "lembaga negara, badan negara, atau organ negara"27

Maka untuk membentuk suatu peradilan baru hanya bisa dilakukan sebagaimana dijelaskan diatas baik itu melalui undang-undang maupun perubahan kelima Undang-Undang Dasar 1945 serta memanfaatkan Lembaga negara yang sudah ada misalnya komisi yudisial untuk menjadi peradilan etik bagi penyelenggara negara.

26 Laporan Hasil Penelitian. (2018). Rekonstruksi Kedudukan Dan Kewenangan Dewan Etik Hakim Konstitusi Sebagai Upaya Memperkuat Integritas Hakim Konstitusi, Kepanitraan Dan Sekretarian Jendral Mahkama Konstitusi.

27 Arifin, Firmansyah, Et,Al,. (2005). Lembaga Negara Dan Sengketa Kewenangan Antarlembaga Negara, Jakarta: Krhn-Mkri-The Asia Foundation Dan Usaid, h. 29. 


\section{P E N U T U P}

Berdasarkan pembahasan diatas maka dapat ditarik kesimpulan bahwa urgensi pembentukan peradilan etik di Indonesia dipengaruhi tiga faktor. Pertama, filosofis. Secara filosofis sebagai staatsfundamental norm, Pancasila menjadi sumber rule of ethic dalam kehidupan berbangsa dan bernegara. Kedua, UUD 1945, Setelah Perubahan UUD 1945 memberikan jaminan pentingnya rule of ethic dalam batang tubuh UUD. Hal ini didasarkan atas frasa imperatif UUD yang memberikan prasyarat good behaviour untuk menjadi seorang pejabat negara. Ketiga sosiologis, dengan semakin banyaknya Lembaga penegak kode etik disetiap rumpun kekuasaan setelah perubahan UUD, menjadi keharusan adanya konsolidasi kelembagaan penegak kode etik dikarenakan lemahnya proses ajudikasi internal yang dilakukan masing-masing lembaga yang dimaksud saat ini. Oleh karena itu, pelembagaan peradilan etik merupakan langkah alternatif untuk menegakkan kode etik agar terciptanya pemerintahan yang berwibawa.

Menggagas peradilan etik bisa dengan dua cara, Pertama, proses pembentukan suatu Lembaga negara atau peradilan etik bisa dibentuk melalui undang-undang. Dalam hal ini kontruksinya peradilan etik dibentuk sebagai lembaga negara yang mempunyai fungsi mengadili terhadap pelanggaran etik penyelenggara negara. Peradilan etik yang dibentuk dalam Undang-Undang harus dilengkapi dengan kewenangan memutuskan yang bersifat final dan mengikat. Kedua pemebntukan peradilan etik dapat dilakukan melalui jalur perubahan kelima UUD 1945, dimana pengaturan terkait pelembagaan peradilan etik diatur dalam konstitusi (constitutionally based power) sehingga menjadi organ penting (constitutional importance) konstitusi dalam mengawal etik dan perilaku pejabat negara. Maka dalam hal pembentukan peradilan etik dilakukan dengan metode reposition, reshaping, dan redundancy terhadap organorgan negara yang telah ada sebelumnya. Misalnya perihal reposition. Mereposisi kedudukan Komisi Yudisial dalam kekuasaan kehakiman sehingga KY tidak hanya menjadi Lembaga penegak kode etik hakim saja tapi menjadikan KY sebagai peradilan etik penyelenggara negara untuk mengadili pelanggaran etik bagi penyelenggara negara di Indonesia sehingga berfungsi sebagai watchdog terhadap penegakan etika dalam tubuh kekuasaan kehakiman.

\section{DAFTAR PUSTAKA}

\section{Jurnal}

[1] Angkasa, Nawa. (2013). Analisis Kedudukan Dan Fungsi Yudikatif Sebagai Pemegang Kekuasaan Kehakiman Dalam Sistem Negara Hukum Di Indonesia. Nizham Journal of $\begin{array}{lllll}\text { Islamic } & \text { Studies. } & 02 & (1), & 84-109 .\end{array}$ journal.metrouniv.ac.id/index.php/nizham/article/view/848.

[2] Eleanora, Fransiska Novita. (2012). Pancasila Sebagai Norma Dasar Dalam Sistem Hukum Indonesia, ADIL Jurnal Hukum. 3 (1), 141-165. https://doi.org/10.33476/ajl.v3i1.838.

[3] Iswandi, Kelik., Prasetyoningsih, Nanik. (2020). Penyelesaian Sengketa Kewenangan Lembaga Negara Independen di Indonesia. SASI, $26 \quad$ (4), 434-446. https://doi.org/10.47268/sasi.v26i4.283.

[4] Nugroho, Irham. (2016). Positivisme Auguste Comte: Analisa Epistemologis Dan Nilai Etisnya Terhadap Sains, Cakrawala Jurnal Studi Islam, 11 (2), 167-177. https://doi.org/10.31603/cakrawala.v11i2.192.

[5] Palese, Emma. (2013). Ethics without Morality, Morality without Ethics-Politics, Identity, Responsibility in Our Contemporary World, Open Journal of Philosophy, 3 (3), 366-371. DOI: 10.4236/ojpp.2013.33055.

[6] Rishan, Idul. (2017). Justifikasi Pelembagaan Peradilan Etik. Dialogia Iuridica: Jurnal Hukum Bisnis Dan Investasi, 9 (1), 092-111. https://doi.org/10.28932/di.v9i1.733. 


\section{Buku}

[7] Asshiddiqie, Jimly. (2014). Peradilan Etika Dan Etika Konstitusi, Jakarta: Sinar Grafika.

[8] Asshiddiqie, Jimly. (2015). Peradilan Etik Dan Etika Konstitusi, Perspektif Baru Tentang Rule Of Law And Rule Of Ethics \& Constitutional Law And Constitutioal Ethics, Jakarta: Sinar Grafika.

[9] Indrati, Maria Farida. (2007). Ilmu Perundang-Undangan 1, Jenis, Fungsi, Dan Materi Muatan, Yogyakarta: Kanisius.

[10] Ismail, (2017). Etika Pemrintahan Norma, Konsep Dan Praktek Pemerintahan, Yogyakarta: Lintang Rasi Aksara Books.

[11] Muhammad, Abdul Kadir. (2006). Etika Profesi Hukum, Bandung: Citra Aditya Bakti.

[12] Santoso, Agus. (2012). Hukum, Moral \& Keadilan Sebuah Kajian Filsafat Hukum, Jakarta: Kencana.

\section{Lain-Lain}

[13]Arifin, Firmansyah, Et,Al,. (2005). Lembaga Negara Dan Sengketa Kewenangan Antarlembaga Negara, Jakarta: Krhn-Mkri-The Asia Foundation Dan Usaid.

[14] Asshidiqie, Jimly. (2006). Perkembangan dan Konsolidasi Lembaga Negara Pasca Reformasi, Jakarta: Sekjen Dan Kepaniteraan.

[15] Ihsan, Fahrul. Ekonomi Pancasila: Gagasan Dan Kemungkinan, Jakarta: Pusataka LP3ES.

[16] Laporan Hasil Penelitian. (2018). Rekonstruksi Kedudukan Dan Kewenangan Dewan Etik Hakim Konstitusi Sebagai Upaya Memperkuat Integritas Hakim Konstitusi, Kepanitraan Dan Sekretarian Jendral Mahkama Konstitusi.

[17] Preston, N. (2000). Local Government, Public Enterprise and Ethics. The Federation Press, 2000.

[18] Suparman, Eman. (2013). Risalah Komisi Yudisial (Cikal Bakal Dan Wewenang), Jakarta : Secretariat Jendral Komisi Yudisial Republic Indonesia. 